\title{
Comparative Analysis of Inbound Tour Operators' Perception of Destination Competitiveness of India and Singapore
}

\author{
Archana Bhatia \\ Associate Prof. Head and Dean Department of Commerce DAV C. College Faridabad
}

\section{Introduction}

There are mainly two players involved in the tourism industry who provide various kinds of services to the tourists whether domestic or international and these are :

\section{Travel Agents}

A travel agent is a retail business agent that sells travel related products and services to customers on behalf of suppliers, railways and may include sight seeing tours and package holidays that combine several products. The agents work on commission basis. They are paid commissions on the products handled. An agent shall not buy the products unless there is a specific customer request.

\section{Tour Operators}

A tour operator sells a 'packaged holiday'-including the hotel, the flight and all other sort of expenses. The business type is similar to a wholesale business where the operating profit is the discount one gets from the providers of tourism products like hotels, shipping agencies, airlines, restaurants, tourist guides etc. They also have cordial relations with various government agencies in the smooth functioning of their activities. They promote complete tour package, which is sold either directly to a customer or through travel agents. As they consolidate all the products under one roof and promote group travel, they are able to provide the services at very competitive rates.

\section{Functions of Tour Operators}

Tour operators consolidate tourism service products under one roof, pertaining to stipulated tour package. They are responsible for the successful completion of tour as originally designed and informed to the customers. They have to make alternative arrangements in case of any disturbances in the stipulated tour. They provide employee assistance wherever possible during the course of the tour. The tour operators arrange standard as well as customized tour packages to meet the customer demand. They coordinate with other partners of the package to ensure proper linkages and fulfillment of the obligation of the package by hotels, travel agents, guides, car rentals etc and provide information pertaining to immigration and other ground rules of different countries. They also provide necessary foreign currency to the travelers and update the information pertaining to tourist traffic to Department of Tourism and other agencies of tourism promotion and development. Tour operating business is an important part of tourism industry, as more and more customers are interested in standard packaged tours where they have the convenience of completing the tour with minimum risk. American Express Company (AMEXO), Thomas Cook, Oriental Express, Cox \& Kings are some of the famous tour operators in the industry. Thus, from the above discussion it is very much clear that while a travel agent acts on the behalf of a company / Principal and undertakes no liability for the Principals' services and that a travel agent is a retail business dealing in travel products on commission basis. Whereas a tour operator holds responsibility for the completion of the tour as they arrange the individual elements in the travel product on their own and combines them in such a way that they are selling a package of traveler tour to the client and as such carries the ownership of the service elements and attached responsibility.

\section{Review of Literature}

Academic literature on the tourism industry in India has spanned across several disciplines from the regional as well as the national perspective. As the largest country in terms of size and population in the South Asian region, India has a large influence on the regional tourism industry. India featured prominently in the work of various scholars Reorienting HRD strategies for tourists' satisfaction- a study by Nageshwar Rao and R.P. Das $(2002)^{[1]}$ sought to highlight how the Indian Tourism Industry can reorient its HRD strategies in order to satisfy and delight its customers to survive in the global competition. With a better qualified younger workforce occupying the positions in the future and with tremendous opportunities opening for them elsewhere, the key task before the policy makers in organizations is to keep the tourist contact employees satisfied. 
Joaquin Alegra Marin and Jaume GaranTaberner's study "satisfaction and dissatisfaction with destination attributes, influence on overall satisfaction and the intention to return" ${ }^{[2]}$ point to the need to reconsider the usual structure of tourist satisfaction surveys. The results of this study illustrate that tourists evaluate the attributes of a destination differently depending on whether the survey elicits an opinion relating to a dimension of dissatisfaction.

"International Tourist satisfaction and destination Loyalty : Bangkok, Thailand"(2010) ${ }^{[3]-}$ a study conducted by Siriporn McDowall tried to compare the demographic characteristics between first time and repeat international tourists in Bangkok and found that overall, international tourists were satisfied with their visit to Bangkok. First time tourists were more satisfied with the visit repeaters as their mean score was higher but there is no statistical difference between these two groups.

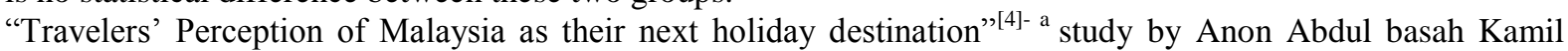
(2010) sought to have information and data on knowledge and perceptions of potential tourists about Malaysia to formulate appropriate and effective marketing and promotional strategies. This study found that knowledge is the most significant factor in determining tourists decision to visit Malaysia except for African, West Asian and South/ Central American tourists.

"Tourist satisfaction with Mauritius as a holiday destination"(2008) ${ }^{[5]-}$ a research work by Perunjodi Ladsawut used the expectancy - disconfirmation model to study the tourist satisfaction across 18 destination attributes as well as overall satisfaction with the destination. Tourists' satisfaction with individual destination attributes revealed that 13 attributes were positively disconfirmed whereas 5 attributes were negatively disconfirmed.

"Tourist satisfaction in Singapore- a perspective from Indonesian tourists" ${ }^{,[6]}$ - a study by Theresia A. Pawitra and Kay C. Tan (2001); analyzed the Indonesian tourists' satisfaction scores about Singapore and showed that from the 'Indonesian tourists' point of view, Singapore Tourism Board was successful in promoting and maintaining the performance of the local tourism industry.

"Factors influencing choice of tourist destinations: A study of North India" (2009) ${ }^{[7]}$ is a research paper by Neeraj Kaushik, Jyoti Kaushik, Priyanka Sharma and Savita Rani. This paper attempted to determine the factors responsible for determining the attractiveness of a tourist destination in North India and found that there are seven factors which are considered important by the tourists while selecting their destinations. These factors arecommunication, objectivity, basic facilities, attraction, support services, distinctive local features and psychological and physical environment.

David Foster's paper "The customer's perception of Tourism Accreditation “[8] sought to know the level of awareness among consumers of the tourism accreditation system in Australia and found that a lot of work needs to be done before we can be confident that consumers are aware of the existence of the tourism accreditation system. It has also demonstrated that even when tourists are aware of accreditation, there is confusion about what it actually means.

"Foreign Visitor's evaluation on tourism environment" $(2010)^{[9]-}$ a study by Takeshi Kurihara, and Naohisa Okamoto sought to understand the relative importance of the items that define the

tourism environment and how foreign visitors evaluate Japan's tourism environment. It discussed the tourism environment evaluation from the viewpoint of the qualitative approach given by the foreign visitor's evaluation $\&$ the quantitative approach which is calculated by the principal component analysis based on the objective data.

\section{Problem Statement and Rationale of the Study}

Tourism is a popular global leisure activity. International tourism is hitting new records every year. Despite the challenging conditions, international tourism being a very important activity, is contributing approximately $5 \%$ of the world's GDP, $6 \%$ of the total exports and employing one out of every 12 people in advanced and emerging economics. World Economic Forum's TTCI 2011 has mentioned the changing trend of international tourism from advanced economics to emerging (developing) economics. Over the last decade the Asia pacific region has been the fastest growing tourism region in the world. This is the reason to select this region for the purpose of my study. If the trend of outbound tourism of India is observed, it is found that Singapore is one of the most preferred destinations by Indians. Moreover, in the list of top ten source countries of foreign tourists for Singapore, India is at the fourth place whereas in the list of top ten source countries of foreign tourists for India, Singapore is nowhere. It reveals that a large number of Indians prefer to visit Singapore whereas Singaporeans are not too much interested in visiting India. 
Table 1

Ranking of India \& Singapore in the World tourism sector and Asia pacific Tourism sector

\begin{tabular}{|c|c|c|c|c|}
\hline \multirow{2}{*}{ Year } & \multicolumn{2}{|c|}{ Ranking in the World Tourism sector } & \multicolumn{2}{|c|}{ Ranking in Asia Pacific Tourism sector } \\
\cline { 2 - 5 } & India & Singapore & India & Singapore \\
\hline 2007 & 65 & 8 & 11 & 8 \\
\hline 2008 & 65 & 16 & 11 & 2 \\
\hline 2009 & 62 & 10 & 12 & 2 \\
\hline 2011 & 68 & 10 & 1 & 1 \\
\hline
\end{tabular}

Source: TTCI published by World Economic Forum (2007-2011)

The above table reveals that the standing of India $\left(68^{\text {th }}\right.$ rank $)$ in the world tourism sector is far behind Singapore $\left(10^{\text {th }}\right.$ rank in 2011) not only in one year rather continuously India has been having lower rank than Singapore. Narrowing down the domain, the comparison of India and Singapore in the Asia Pacific Region as depicted in the table conveys that ranking of Singapore in this region is continuously improving whereas India's rank is continuously showing a declining trend. In the Asia Pacific Region, Singapore is the leading country whereas inspite of having huge natural, cultural and heritage resources India is far behind it. This contrast really made the researcher to choose this topic for research study.

Thus the present research work has been conducted keeping in view the following objectives:

\section{Objectives of the Study:}

1. To examine the perception of tour operators regarding various attributes affecting destination competitiveness of Indian tourism industry.

2. To examine the perception of tour operators regarding various attributes affecting destination competitiveness of Singapore tourism industry.

3. To carry out a comparative analysis of perception of tour operators regarding various attributes affecting destination competitiveness of Indian and Singapore tourism industry.

4. To examine the perception of tour operators regarding the attribute of prices of India.

5. To examine the perception of tour operators regarding the attribute of prices of Singapore.

6. To carry out a comparative analysis of perception of tour operators regarding the attribute of prices of India and Singapore.

\section{Hypotheses Formulation}

In order to accomplish the above mentioned objectives following null hypotheses have been formulated:

$H_{01}:$ There is no significant difference in the perception of the tour operator for various attributes affecting destination competition of India and Singapore

$H_{02}$ : There is no significant difference in the perception of tour operators regarding the attribute of prices of India and Singapore.

\section{Research Methodology}

A structured questionnaire was filled by the tour operators dealing in international tour packages. In total, opinion of 90 tour operators from India and 30 from Singapore have been collected for analysis purpose. The questions were of multiple choices and efforts were made to keep the questionnaires free from biasness. To measure the intensity of their responses, a five point Likert scale was used for most of the questions.

\section{Tools of Data Analysis}

Before analyzing the data, its reliability has been checked by calculating Chron Bach Alpha that comes out to be 0.67 . It shows that the data collected is reliable. After confirming the reliability of data collected, the data have been analyzed using independent sample t- test and on SPSS version 18.

\section{Analysis of Data Collected from Tour Operators}

In the following section an attempt is made to analyze the perception of tour operations of both destinations.

i) In India, 'spiritual', 'medical', 'adventure and wildlife', 'rural' and 'cultural and heritage' tourism is mostly preferred by the foreign tourists in the opinion of Indian tour operators.

ii) In the opinion of tour operators of Singapore, their country is particularly preferred for 'eco-tourism', 'adventure and wildlife tourism' and 'educational tourism' as shown in the tables 2 to 8 
Table 2

Responses for Inbound Tourist's Visit for Spiritual Tourism

\begin{tabular}{|c|c|c|c|c|}
\hline \multirow{2}{*}{} & \multicolumn{3}{|c|}{ Eco Tourism } \\
\cline { 2 - 5 } & \multicolumn{2}{|c|}{ India } & \multicolumn{2}{c|}{ Singapore } \\
\cline { 2 - 5 } & Frequency & Percentage & 22 & Percentage \\
\hline Yes & 58 & 64.4 & 8 & 26.3 \\
\hline No & 32 & 35.6 & 30 & 100 \\
\hline Total & 90 & 100 & 30 & \\
\hline
\end{tabular}

Table 3

Responses for Inbound Tourist's Visit for Eco Tourism

\begin{tabular}{|c|c|c|c|c|}
\hline \multirow{2}{*}{} & \multicolumn{4}{|c|}{ Rural Tourism } \\
\cline { 2 - 5 } & \multicolumn{2}{|c|}{ India } & Frequency & Percentage \\
\cline { 2 - 5 } & Frequency & Percentage & 01 & 3.4 \\
\hline Yes & 53 & 58.4 & 29 & 96.6 \\
\hline No & 37 & 41.1 & 30 & 100 \\
\hline Total & 90 & 100 & & \\
\hline
\end{tabular}

Table 4

Responses for Inbound Tourist's Visit for Rural Tourism

\begin{tabular}{|c|c|c|c|c|}
\hline \multirow{2}{*}{} & \multicolumn{4}{|c|}{ Medical Tourism } \\
\cline { 2 - 5 } & \multicolumn{2}{|c|}{ India } & Frequency & Percentage \\
\cline { 2 - 5 } & Frequency & Percentage & 10 & 33.3 \\
\hline Yes & 65 & 72.2 & 20 & 66.7 \\
\hline No & 25 & 27.8 & 30 & 100 \\
\hline Total & 90 & 100 & & \\
\hline
\end{tabular}

Table 5

Responses for Inbound Tourist's Visit for Adventure \&Wildlife Tourism

\begin{tabular}{|c|c|c|c|c|}
\hline \multirow{2}{*}{} & \multicolumn{4}{|c|}{ Adventure \& Wildlife } \\
\cline { 2 - 5 } & \multicolumn{2}{|c|}{ India } & Frequency & Percentage \\
\cline { 2 - 5 } & Frequency & Percentage & 19 & 63.3 \\
\hline Yes & 68 & 75.6 & 11 & 36.7 \\
\hline No & 22 & 24.4 & 30 & 100 \\
\hline Total & 90 & 100 & & \\
\hline
\end{tabular}

Table 6

Responses for Inbound Tourist's Visit for Medical Tourism

\begin{tabular}{|c|c|c|c|c|}
\hline \multirow{2}{*}{} & \multicolumn{4}{|c|}{ Educational Tourism } \\
\cline { 2 - 5 } & Frequency & Percentage & Frequency & Singapore \\
\cline { 2 - 5 } & 48 & 53.3 & 21 & 70 \\
\hline Yes & 42 & 46.7 & 9 & 30 \\
\hline No & 90 & 100 & 30 & 100 \\
\hline Total & & & & \\
\hline
\end{tabular}

Table 7

Responses for Inbound Tourist's Visit for Cultural Tourism

\begin{tabular}{|c|c|c|c|c|}
\hline \multirow{2}{*}{} & \multicolumn{4}{|c|}{ Spiritual Tourism } \\
\cline { 2 - 5 } & \multicolumn{2}{|c|}{ India } & Frequency & Singapore \\
\cline { 2 - 5 } & Frequency & Percentage & 8 & 26.7 \\
\hline Yes & 68 & 75.6 & 22 & 73.3 \\
\hline No & 22 & 24.4 & 30 & 100 \\
\hline Total & 90 & 100 & & \\
\hline
\end{tabular}

Table 8

Responses for Inbound Tourist's Visit for Educational Tourism

\begin{tabular}{|c|c|c|c|c|}
\hline \multirow{2}{*}{} & \multicolumn{4}{|c|}{ Cultural heritage } \\
\cline { 2 - 5 } & Frequency & Percentage & Frequency & Percentage \\
\cline { 2 - 5 } & 78 & 86.7 & 16 & 53.3 \\
\hline Yes & 12 & 13.3 & 14 & 46.7 \\
\hline No & 90 & 100 & 30 & 100 \\
\hline
\end{tabular}


The perception of the tour operators regarding the destination competitiveness of India and Singapore was compared on nine attributes viz, security and safety, maintenance and cleanliness information and communication infrastructure, natural attraction, man-made attraction, facilities at tourist spots, behavior of country residents and prices. The prices attribute was further divided into six variables.

In order to test the difference in the perception of the tour operators for the various attributes of destination competitiveness the following null hypothesis was formulated

$H_{01}$ : There is no significant difference in the perception of the tour operator for various attributes affecting destination competition of India and Singapore

Independent sample t-test was applied to test the hypothesis $\mathrm{H}_{01}$, the results of which are shown in the following table:

Table 9

Independent Sample T-test for Different Attributes of Destination Competitiveness of India and Singapore

\begin{tabular}{|l|l|l|l|}
\hline Attribute & Country & Mean(SD) & $\begin{array}{l}\text { T Stats } \\
(\text { P Value) }\end{array}$ \\
\hline Safety \& Security & India & $2.60(.903)$ & 8.612 \\
& Singapore & $4.46(.588)$ & $(.000)$ \\
\hline Maintenance & India & $2.80(.528)$ & 12.690 \\
& Singapore & $4.50(.590)$ & $(.000)$ \\
\hline Information \& & India & $4.02(.598)$ & 3.896 \\
Communication & Singapore & $3.29(1.042)$ & $(.000)$ \\
\hline Infrastructure & India & $2.80(.636)$ & 8.626 \\
& Singapore & $4.33(.602)$ & $(.000)$ \\
\hline Natural Resources & India & $4.28(.626)$ & 6.214 \\
& Singapore & $3.13(.992)$ & $(.000)$ \\
\hline Man Made Attractions & India & $2.85(.868)$ & 8.598 \\
& Singapore & $4.54(.588)$ & $(.000)$ \\
\hline Facilities & India & $2.89(1.003)$ & 6.0594 \\
& Singapore & $4.25(.666)$ & $(.000)$ \\
\hline Behavior of Country & India & $3.00(.932)$ & 6.082 \\
Residents & Singapore & $4.29(.690)$ & $(.000)$ \\
\hline
\end{tabular}

Table 9 reveals that the value of statistics for all the attributes of destination competitiveness is less than 5 percent level of significance. Hence, at 95 percent level of confidence, the null hypothesis $\mathrm{H}_{\mathrm{ol}}$, is rejected which conveys that there exists a significant difference in the perception of tour operator for the various attributes affecting destination competitiveness of India and Singapore.

Moreover, the mean scores indicate that for the attributes of safety and security maintenance of cleanliness, infrastructure, man-made attractions, facilities at tourists spots and behavior of country residents the standing of Singapore is significantly better than India in the opinion of the tour operators.

However, for the attributes of information and communication and natural resources, the position of India is significantly better than that of Singapore in tour operator's opinion. Further, to compare the difference in the perception of tour operators regarding price competitiveness of India and Singapore the following null hypothesis has been formulated.

$\mathrm{H}_{02}$ : There is no significant difference in the perception of tour operators regarding the attribute of prices of India and Singapore.

Independence sample t-test was applied to check the above mentioned null hypothesis which reveals the following results:

Table 10

Independent Sample T-test on Prices Attribute

\begin{tabular}{|l|l|l|l|}
\hline Prices & COUNTRY & MEAN(SD) & $\begin{array}{l}\text { T STATS } \\
\text { (P VALUE) }\end{array}$ \\
\hline Accommodation & India & $2.31(.696)$ & 11.020 \\
& Singapore & $4.50(.834)$ & $(.000)$ \\
\hline Food & India & $4.48(.666)$ & 10.930 \\
& Singapore & $2.66(.602)$ & $(.000)$ \\
\hline Local Transport & India & $4.35(.955)$ & 8.062 \\
& Singapore & $2.63(.646)$ & $(.000)$ \\
\hline Airfare Charges & India & $2.86(1.388)$ & .609 \\
& Singapore & $3.08(.616)$ & $(.480)$ \\
\hline Shopping & India & $4.151 .053)$ & 6.884 \\
& Singapore & $2.54(.658)$ & $(.000)$ \\
\hline Food & India & $4.24(.960)$ & 8.131 \\
& Singapore & $2.50(.590)$ & $(.000)$ \\
\hline
\end{tabular}


Table 10 highlights that except for the variable of 'air-fare charges' the p-value of t-statistics for all the others variables was less than 5 percent level of significance. Hence, at 95 percent of confidence the null hypothesis $\mathrm{H}_{04 \mathrm{~b}}$ for these variable is rejected which conveys that there is a significant difference in the perception of tour operators regarding all the variables of price attribute except for the variable of 'air-fare charges'. It is also observed from the mean scores that the prices of food, local transportation fare, shopping goods and food and other commodity prices are more reasonable in India in comparison to Singapore. However, the price of accommodation and air-fare is cheaper in Singapore than India in the opinion of tour operators.

The respondents were also asked whether India and Singapore are equally preferred destinations in the Asiapacific region by the international tourists. Interestingly, 100 percent of the respondents were of the opinion that both India and Singapore are not equally preferred destination. Moreover, Singapore is a more preferred destination than India in the view of respondents.

\section{Conclusion}

There is a significant difference in the perception of tour operators of both the destinations regarding all the attributes of destination competitiveness of India and Singapore. In case of safety and security, maintenance and cleanliness, infrastructure, man made attractions, facilities at tourists spots and behavior of local residents Singapore has better standing in comparison to India in the opinion of tour operators whereas for the attribute of natural resources and information and communication India's position is better than Singapore. The price attribute which consisted of six variables was particularly taken in detail as tour operators can best tell the price issues. The findings highlight that there is a significant difference in the perception of tour operators of both the destinations. It is also found that for prices of food, local transportation fare, prices of shopping goods and food and other commodity prices at tourist's spots are found to be more reasonable in India as compared to Singapore. However, the prices of accommodation and air fare are more reasonable in Singapore than in India.

\section{References}

[1]. R.P.Das, Nageshwar Rao (2002) ${ }^{1}$,Journal of services Research,volume 2,number 1(April-september ,2002)

[2]. Joaquin Alegre Marin, joaquin. Alegre @uib.es / jaume.garau@uib.cat, Second International Conference on Tourism Economics (Palma, 2006), International Conference of Trends, Impacts and Policies onTourism Development (Crete, 2006).

[3]. Siriporn Mc Dowell (2010) ${ }^{1}$, Asia Pacific Journal of Tourism Research, Volume 15, Number 1, March 2010

[4]. Anton Abdulbasah Kamil(2010), ozean Journal of social Sciences 3(2),2010 ISSN 1943-2577

[5]. Perunjodi Naidoo, Prabha Ramseook Munhurrun, Jeynakshi Ladsawut (2008), global journal of business ,vol 4, no. 2,2010

[6]. Theresia A. Pawitra and Kay C. Tan (2001),Managing service quality vol-13,no.5 2003,pp 399-411

[7]. Neeraj Kaushik, Jyoti Kaushik,Priyanka Sharma \& Savita Rani (2009), The IUP journal of brand Mgt,Vol. VII, Nos. 1 \& 2,2010

[8]. David Foster, Centre for Management Quality Research, RMIT University

[9]. Takeshi Kurihara, Naohisa Okamoto(2010),Journal of The Eastern Asia Society for Transportation studies, vol .8,2010 